\title{
水路床上に存在する半球下流部の流れの構造に関する実験的研究 THE EXPERIMENTAL STUDY ON THE STRUCTURE OF TURBULENT FLOW BEHIND A HEMISPHERE ON THE BED
}

\author{
高橋 迪夫* \\ By Michio TAKAHASHI
}

\begin{abstract}
The study on the structure of turbulent flow behind a hemisphere on the bed seems to offer a fundamental information on the energy loss in a boulder-bed stream or the flow characteristics around the river constructions such as the foot protection block.

In this paper, the mean-velocity distribution and turbulence characteristics behind a hemisphere on the bed are studied in detail. The equation of mean-velocity distribution is obtained in the connection between axisymmetric wake and logarithmic law, and the values are compared with those which are observed. The turbulent structure can be explained on the basis of examination on the distributions of Reynolds stress and turbulent kinetic energy, and the energy balance.
\end{abstract}

Keywords: hemispherical roughness, wake flow, mean-velocity distribution, turbulent structure

\section{1. まえがき}

水路床上に存在する半球の周辺，特に下流部の流れの 平均流速分布, 乱流特性等の流れの構造を明らかにする ことは, 礫床河川における平均的河床面加ら突出して点 在する巨砂の流れの抵抗等に及ぼす影響, あるいは三次 元的な形状を有する根固めブロック等の河川構造物周辺 の流れの特性を検討していくための基礎特性の把握とし て重要であろう。

水工学上の問題における二次元的な形状を有する粗 度 ${ }^{11}$, 障害物 ${ }^{2}$, 河床波 ${ }^{3,4)}$, あるいは段落与等の断面変 化部 ${ }^{510}$ (1) の流部の剝離を伴う流れに対する流れの構造 に関しては，種々の検討が加えられてきている，一方， 本報で対象としている半球下流部における流れは, 水路 床の存在に加えて，半球上方および側方からの流れ込み によって流れの混合, 平均化が進み, その結果, 二次元 後流の流れに比べて, 剥離域が減少するとともに後流域 の広がりが緩やかとなり，平均流速欠損の回復が速めら れると考えられる。ささらに，後流混合域と剝離域との境 界全域にわたる乱れの生成によって複雑な乱流構造にな ることが推測され，後流域に対する三次元的な取扱いが

* 正会員 日本大学助教授 工学部土木工学科 （テ963 郡山市田村町徳定中河原 1)
必要であろう。また，半球下流部の流れの中でも，特に 半球に近い領域は流れの構造の変化が急激であり, 解析 的に表現しにくい部分である. しかしながら，半球によ る流れのエネルギー損失の大部分がこの領域で生ずると 考えられ，流れの抵抗特性，エネルギ一損失機構，さら には砂砅の流送過程等の問題を明らかにしていくうえで 半球が流れに及ぼす影響を把握するためには, 半球に近 い領域に対する検討が重要になってくるであろう。この ような三次元的な形状の物体下流部の流れの構造に関し ては, Chen ら ${ }^{11)}$, 神田ら ${ }^{12)}$, Okamoto $\left.{ }^{13)}, 14\right)$, 玉井ら ${ }^{15)}$ 等によって検討がなされてきている.しかしながら，相 対水深が小さく，しかもフルード数が大きく異なる流れ における半球下流部の平均流速分布，および乱れエネル ギーの生成, 逸散過程に主眼を置いた乱流構造の変化に ついては，それほど多くの報告は見受けられず，検討を 要する事項がまだ残されているように思われる.

本報は, 水路床上に存在する半球下流部の半球に近い 領域における流れの構造が, フルード数あるいは相対水 深の相違によってどのように変化するかを, 後流幅, 剝 離長さ, 平均流速分布等の平均流特性ならびに乱れエネ ルギー, レイノルズ応力, エネルギー収支等の乱れ特性 の面から実験的に考察し, 合わせて, 自由後流の理論に よって本報の流れの特性がどの程度まで説明され得るか 
を検討したものである，なお，本報では，半球下流部の 流下中心軸上の特性を中心に検討が展開されているが， これは，流下中心軸上においても半球上方，側方からの 流れ込みによる三次元的な特性は把握できるであろうと いう点之，さらに，工学的な問題の巨碩あるいは根固め ブロック床上の流れのように，大きな粗度がかなり密に 配列された境界面上の流れにおいては，平均化された流 下軸上に対する取扱いとなるであろうという考えに基づ いている。

\section{2. 実験装置および方法}

実験に用いた水路は, 長さ $8 \mathrm{~m}$, 幅 $B=25.0 \mathrm{~cm}$ のア クリライト製のものであり，上流端より約 $4.7 \mathrm{~m}$ の水 路底面中央部に半径 $k=1.92 \mathrm{~cm}$ のプラスチック製半球 が設置されている.

実験は，半球近傍の流れの基本的な特性をできる限り 詳細に把握するという観点から, 計測点を流れの変化の 大きい部分では細かく設け, 流下 $(x$ 軸 $)$ 方向には $1 \mathrm{~cm}$, 水深 $(y$ 軸) および横断 ( $z$ 軸) 方向には $1 \sim 2 \mathrm{~mm}$ の 格子状に設定して行われた。乱流計測には，円錐および X型プローブをセンサーとしたホットフィルム流速計が 用いられた. 流況の可視化はアルミ粉末およびフルオレ セインナトリウム溶液を用いたトレーサー法によって行 い, 剝離長さの目視観測にはトレーサーとして過マンガ ン酸カリウム溶液が用いられた。また, 半球背後の逆流 域の流向の確認は，小型プロペラ流速計のプロペラの回 転方向およびトレーサーによってなされた。なお，ホッ トフィルム流速計は高せん断層の計測に対しては，量的 な面で若干問題があることが指摘されている.

実験条件が Table 1 に，主な使用記号が Fig. 1 に示さ れている.ここに，表中の $\bar{u}_{*_{b}}$ は次式で表わされる水

Table 1 Experimental conditions.

\begin{tabular}{|c|c|c|c|c|c|c|c|c|}
\hline Case & i & $\left.\begin{array}{c}Q \\
\left(\mathrm{~cm}^{3} / \mathrm{s}\right)\end{array}\right)$ & $\begin{array}{c}\mathrm{H} \\
(\mathrm{cm})\end{array}$ & $\begin{array}{l}u_{m}(\mathrm{~cm} / \mathrm{s}) \\
(\mathrm{Q} / \mathrm{BH})\end{array}$ & $\begin{array}{l}\overline{\mathrm{u}^{* b}} \\
\mathrm{(cm} / \mathrm{s})\end{array}$ & $\begin{array}{c}\mathrm{Fr}_{\mathrm{r}} \\
(\mathrm{m} / \mathrm{gR})\end{array}$ & $\begin{array}{c}R_{e} \\
\left(U_{m} / \nu\right)\end{array}$ & $\frac{1}{k}$ \\
\hline$F-1$ & $1 / 1000$ & 4600 & 5.52 & 33.3 & 1.98 & 0.54 & $1.12 \times 10^{4}$ & 2.6 \\
\hline$F-2$ & $1 / 563$ & 6750 & 5.60 & 48.2 & 2.65 & 0.78 & 1.68 & 2.4 \\
\hline$F-3$ & $1 / 246$ & 11330 & 5.56 & 81.5 & 3.99 & 1.33 & 2.75 & 2.3 \\
\hline$F-4$ & $1 / 191$ & 13650 & 5.53 & 98.7 & 4.51 & 1.61 & 3.00 & 2.2 \\
\hline$R-1$ & $1 / 1020$ & 1860 & 2.88 & 25.8 & 1.53 & 0.54 & 0.55 & 2.6 \\
\hline$R-3$ & $1 / 1200$ & 7090 & 7.74 & 36.6 & 2.00 & 0.54 & 1.64 & 2.6 \\
\hline
\end{tabular}

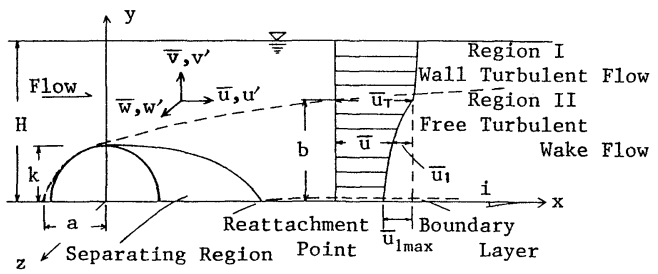

Fig. 1 Regions of wake flow behind a hemisphere.
路底面の平均摩擦速度 ${ }^{16)}$ であり, 式 (1) 〜 (4) を連 立に解くことにより求まる。

$$
\begin{aligned}
& \bar{u}_{* b}=K\left\{\ln \left(\frac{B}{2 y^{\prime}}\right)-1\right\} \\
& \bar{u}_{* w}=K\left\{\ln \left(\frac{H}{z^{\prime}}\right)-1\right\} \\
& K=\sqrt{g R i} \\
& \cdot \sqrt{\frac{1+(2 H / B)}{2 H / B\left[\left(\ln \left(H / z^{\prime}\right)-1\right\}^{2}+1\right]+\left[\left(\ln \left(B / 2 y^{\prime}\right)-1\right\}^{2}+1\right]}} \\
& y^{\prime}=0.111 \nu / \bar{u}_{* w}, \quad z^{\prime}=0.111 \nu / \bar{u}_{* b}
\end{aligned}
$$

ただし， $\bar{u}_{* w}$ ：側壁の平均摩擦速度．ちなみに，本報の 流れにおいては, $\bar{u}_{*_{b}} / \sqrt{g R i}=1.02$ となる。また，lは 最長部の剝離長さであり，半球中心から流速の時間的な 平均が 0 , すなわち, 順流と逆流が同程度に生ずる位置 までの長さとして定義された。

Case F の実験ケースは，相対水深 $H / k$ をほぼ一定 に保ち，フルード数 $F r$ の相違によって流れの構造が どのように変化するかをみようとしたものであり,一方， F-1 および Case R の実験ケースは，一定のフルード数 における流れの構造に及ぼす相対水深の影響をみようと したものである.

\section{3. 実験結果および考察}

\section{（1）平均流特性}

\section{a）流れの領域分け}

半球下流部の流れが，巨視的にみて，Fig. 1 に示すよ うに，半球の上流側の流れの特性が保存される，いわゆ る壁面乱流における対数流速分布則が成り立つ領域 I, および半球背後の剝離域と後流混合域との境界のせん断 層において生成される乱れが支配的で，自由乱流後流亡 しての特性が卓越する流域 II に区分されるものと仮定す る.同様な取扱いは，栈粗度上の流れを二次元後流と壁 面乱流との組合せとした山岡の研究1)，あるいは，山岡 と同じ考え方を球形粗度下流部の流れに適用した神田ら の研究12)等にみられる。なお，流域 II の流れが路床面に 到達する再付着域の下流側からは壁面境界層が再形成さ れるが，石川7 の段落ち流れの結果等を参考にすると， 本報の主として対象としている，半球による流れの工ネ ルギー損失が支配的で，流れの構造が流下方向に大きく 変化する $x / k$ の 10 程度までの範囲の流れにおいては, その領域の影響はそれほど大きくないものと考えられ， 本検討においては省略されている.

以上の考察を踏まえて，半球下流部の流下中心軸上の 平均流速分布式を検討していく．領域 Iにおいては，半 球の上流側からの流れがその特性を保ちながら半球上方 に流れ込み，その結果，接近流における特性が卓越する 
と考えれば，この領域の平均流速分布は次の対数分布式 で表わすことが許されよう.なお，領域 Iが式（5）に よってほぼ表現され得ることは後の Fig. 2 によって確か められる.

$$
\frac{\bar{u}}{\bar{u}_{* b}}=5.75 \log \frac{\bar{u}_{* b} y}{\nu}+5.5 \quad(b<y \leqq H)
$$

ただし， b は，路床面から領域ＩとII の境界までの高さ， すなわち後流の幅である.

一方, 領域 II の流れは, Fig. 5 にみられるように再付 着域下流の底面近傍を除いて自由後流の特性が卓越して いると考えられ，この領域に対して自由後流に関する関 係を適用することが許されよう. 軸対称後流における後 流の幅 $b$, 半值半幅 $b_{1 / 2}$, および最大欠損流速 $\bar{u}_{1 \max }$ に 対する相似解は，それぞれ次のように表現される ${ }^{17)}$.

$$
\begin{aligned}
& b=\sigma_{1}\left(C_{D T} k^{2} X_{0}\right)^{1 / 3} \ldots \ldots \ldots \\
& b_{1 / 2}=\sigma_{2}\left(C_{D T} k^{2} X_{0}\right)^{1 / 3} \ldots \ldots \\
& \frac{\bar{u}_{1 \max }}{\bar{u}_{T}}=\alpha C_{D T}^{1 / 3}\left(\frac{X_{0}}{k}\right)^{-2 / 3} .
\end{aligned}
$$

ここに, $\bar{u}_{T}$ : 領域 I とII の境界における流速, $X_{0}$ : 後 流の始まる点を原点とした座標で, $X_{0}=x+a, a$ : 座 標原点と実際の後流始点との距離, $C_{D T}$ : 代表流速とし て $\bar{u}_{T}$ を用いた半球に対する抗力係数, $\sigma_{1}, \sigma_{2}$ : 実験定 数.

物体から十分離れた下流部における軸対称後流の欠損 流速 $\bar{u}_{1}$ は, 久損流速およびせん断応力の分布の相似性 を仮定すると，次式で表わされる ${ }^{18)}$.

$$
\frac{\bar{u}_{1}}{\bar{u}_{1 \max }}=\exp \left(-\frac{\xi^{2}}{\beta}\right) \text {. }
$$

ここに, $\xi=y /\left(k^{2} X_{0}\right)^{1 / 3}$.

$\beta$ および式（8）の $\alpha$ は，それぞれ半值半幅の定義お よび運動量則より,

$$
\begin{aligned}
& \beta=1.44 \sigma_{2}^{2} C_{D T}^{2 / 3} \cdots \cdots \cdots \cdots \cdots \\
& \alpha=C_{D T}^{2 / 3} / 2 \beta=1 / 2.88 \sigma_{2}^{2}
\end{aligned}
$$

となり,その結果, 式 $(8),(11)$, および $(9)$ より, 領域 II における半球の流下中心軸上の平均流速分布は, 摩擦速度で無次元化すると次式で表わされる.

$$
\frac{\bar{u}}{\bar{u}_{* b}}=\left[1-\frac{C_{D T}^{1 / 3}}{2.88 \sigma_{2}^{2}}\left(\frac{X_{0}}{k}\right)^{-2 / 3}\right.
$$

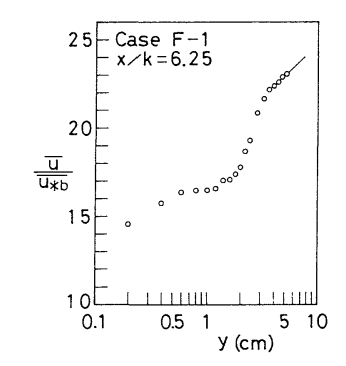

Fig. 2 Mean-velocity distribution.

2 Mean-velocity distribution.

$$
\left.\cdot \exp \left(-\frac{\xi^{2}}{1.44 \sigma_{2}^{2} C_{D T}^{2 / 3}}\right)\right] \frac{\bar{u}_{T}}{\bar{u}_{* b}} \quad(0<y \leqq b)
$$

b) 後流の幅

流れの領域を区分するために，後流の幅 $b$ を次の 2 つの考え方を併用して決定する。

まず，平均流速の測定值 $\bar{u} / \bar{u}_{* b}$ を $\log y$ に対してプ ロットした一例が Fig. 2 である.この図のように, 領域 $\mathrm{I}$ では $\bar{u} / \bar{u}_{* b}$ の分布は 5.75 の傾きをもつ直線上にプ ロットされるはずであり，この直線からはずれる位置が I とII の領域の境界と考えられる. この考えによって求 められた $b$ の值を示したのが Fig. 3 の○印である.

しかしながら，流下が進み領域の境界が水面に接近し て領域 I が減少していくに伴い，直線から外れる位置の 判定が不明確になる.

次に，後に乱れエネルギーの項で示される Fig. 11 に おいて, 半球下流部における乱れエネルギー $\bar{q}^{\prime 2}$ と平均 流エネルギー $\bar{u}^{2}$ の比 $\left(\bar{q}^{\prime 2} / \bar{u}^{2}\right)$ が接近流 $(x / k=-26.0)$ におけるその比 $\left(\bar{q}^{\prime 2} / \bar{u}^{2}\right)_{\infty}$ と等しくなる位置すなわち $\left(\bar{q}^{\prime 2} / \bar{u}^{2}\right) /\left(\bar{q}^{\prime 2} / \bar{u}^{2}\right)_{\infty}=1$ のコンターラインは領域 I と II の 境界に対応しているものと考えられる. この考え方に基 ゔいて Case F-1 に対して求められた $b$ の值を示すと Fig. 3 の $\Delta$ 印となる. 図より，両者の結果はほぼ一致し ている.ただし $\bar{q}^{\prime 2}=\bar{u}^{\prime 2}+\bar{v}^{\prime 2}+\bar{w}^{\prime 2}$ ，また， $\bar{u}^{\prime}, \bar{v}^{\prime}, \bar{w}^{\prime}:$ 各方向の乱れ速度の時間平均値.

Fig. 3 より, 多少のばらつきはあるが, 実験值は式 $(6)$ の関数形にほぼ従っていることが認められる。ただし， 式（6）の $\sigma_{1}$ および $a$ は，実験值に合うように決定さ れ, $\sigma_{1}=1.45, a=1.92 \mathrm{~cm}$ の值をとる. これより，半 球下流部における後流域の流下方向への広がりは二次元 後流の広がり $b \propto X_{0}^{1 / 2}$ に比べて幾分緩やかとなり，ま た，抗力係数が小さくなるほど後流の幅も小さくなって いることが理解される.

なお，本報における抗力係数 $C_{D T}$ は，前述のように， I と II の境界における流速 $\bar{u}_{T}$ を代表流速として定義さ れており，その結果，流下距離によって $\bar{u}_{T}$ が変化する のに伴って $C_{D T}$ の值もわずかながら変化することにな る.この $C_{D T}$ の值は, Flammer ら ${ }^{19)}$ および著者ら ${ }^{20)} の$

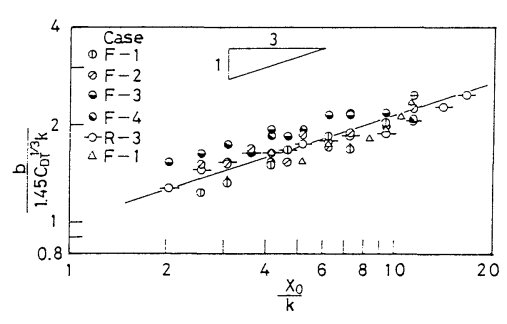

Fig. 3 Longitudinal increase in width of wake $b$.

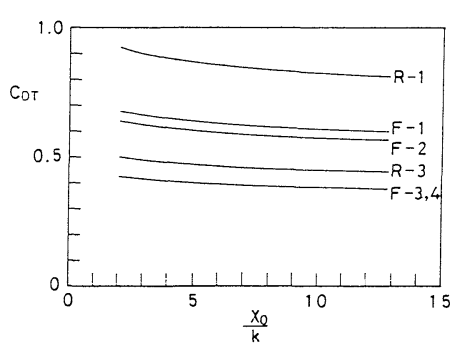

Fig. 4 Drag coefficient. 
実験によって求められた抗力係数 $C_{D H}$ (接近流の半球流 下中心軸上の平均流速 $U_{H}$ を代表流速とした抗力係数） の值から， $C_{D T}=C_{D H} \cdot\left(U_{H} / \bar{u}_{T}\right)^{2}$ によって算出された.

Fig. 4 は, 各実験ケースに対する $C_{D T}$ の值である.

c) 後流の半值半幅

領域 II における久損流速 $\bar{u}_{1}$ の測定値を対数・二乗グ ラフ上にプロットした一例がFig.5である. 式（9）よ りわかるように，この表示を用いると自由乱流後流にお いては，測定值は直線上にプロットされるはずである. 図より，路床面近傍でははずれてくるが，それ以外では 欠損流速はほぼ直線的に分布していることが認められ, 本報で対象としている半球に近い流域においては, 領域 II は, 路床面近傍を除くほとんどの領域で自由後流とし ての特性が支配的であることが理解される．これより， 領域 II 全域に自由後流としての取扱いを許すと, 図の $y$ $=0$ における $\bar{u}_{1}$ の值として最大欠損流速 $\bar{u}_{1 \max }$ が得ら れ, さらに, $\bar{u}_{1 \max } / 2$ における $y$ の值から半值半幅 $b_{1 / 2}$ が求まる，ただし，直線からはずれる路床面近傍を対象 とする場合には，この自由後流としての取扱いをそのま ま当てはめることには問題があろう。このようにして求 められた $b_{1 / 2}$ の值が Fig. 6 に示されている.この図よ り，ばらつきは多少あるが，半値半幅に対する式（7) の関数形は実験值の傾向をほぼ表現していると考えら れ, その結果, $\sigma_{2}=0.55$ が得られる. また, 後流の幅 と半値半幅との関係はほぼ $b=2.6 \cdot b_{1 / 2}$ となる.

なお,この $\sigma_{2}$ の值は, 自由乱流中の球の後流に対す るUberoi ら ${ }^{21), 22)}$ の結果 0.71 に比べると若干小さい值

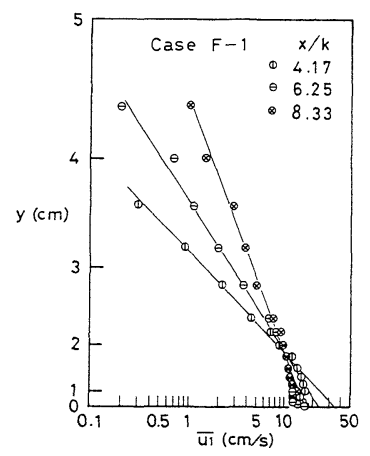

Fig. 5 Defect velocity distribution.

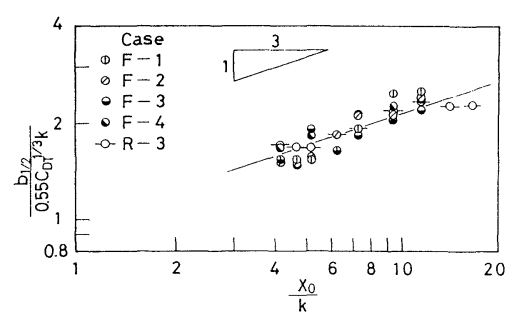

Fig. 6 Longitudinal increase in width of wake $b_{1 / 2}$.
となっている.

\section{d）平均流速分布}

Fig. 7 は, 半球の流下中心軸上における流下方向の時 間平均流速の測定值と, 上述の検討によって求められた 流速分布式（5）および（12）とを比較したものである. 図より, $H / k>3$ で波状的な水面変動を生じない流れの Case F-1 および F-3の $x / k$ が 5 程度よりも下流にお いて, 全体的には式（12），（5）と測定値とのある程度 の一致がみられるようになる。しかしながら，それより も上流側においては，路床面側でかなり大きく相違して くる．これは，この領域においては，欠損流速が $\bar{u}_{T}$ に 比べて小さいという，式（12）に含まれている仮定に無 理があるためと考えられる．また，後に乱れ特性の項で 細かく検討されるように, 再付着域直下流部の路床面側 は，半球上方および側方からの流れ込みと路床面の存在 によって流れの三次元性が特に強く,さらに，乱れエネ ルギーが大量に輸送・拡散され, 逸散される領域であり, この領域での分布式の適合性を良くするためには，これ らの特性の影響も考慮していく必要があろう．次に，常 流の Case F-1 と射流の F-3 とを比較すると, 常流に

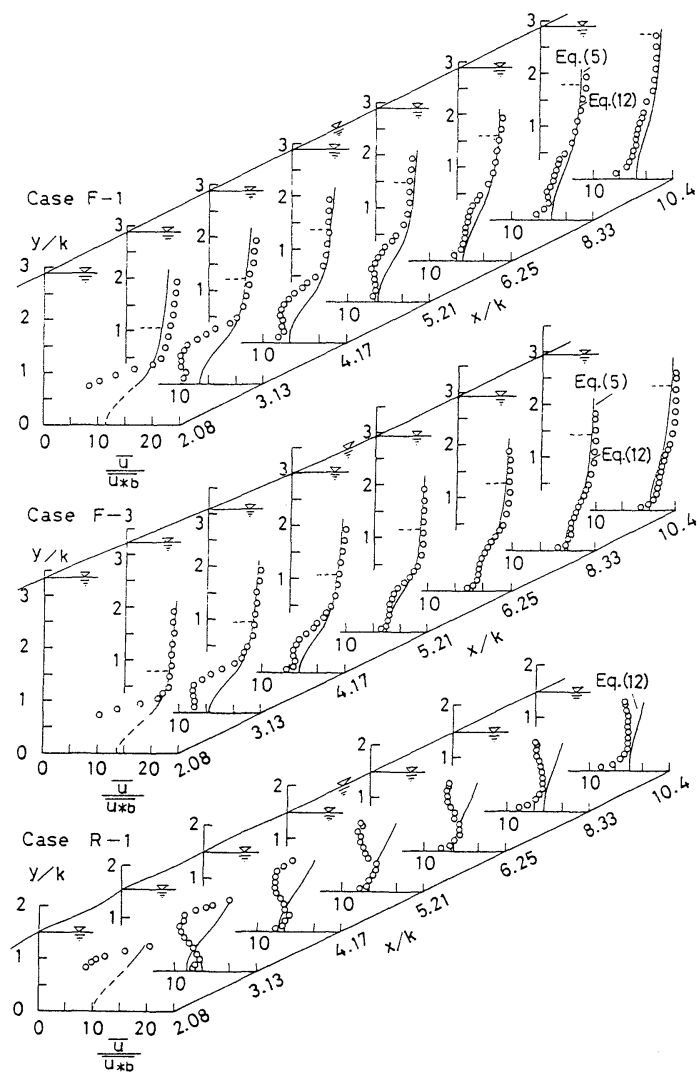

Fig. 7 Comparisons of observed and calculated distributions of mean-velocity. 
比べて射流の方が流速欠損の流下方向の回復が若干速ま り, 半球により近い領域から分布式との全体的な一致が 認められるようになる。これは，常流に比べて射流の方 が剝離長さがやや短くなる（Table 1 参照）とともに, 半球を越えた流れの後流域への流れ込みが水面勾配を もってより強く生じているためと考えられる，射流の流 速欠損の回復が常流に比べて速まるという特性は禰津 ら ${ }^{10)}$ の段落ち流れにおいても認められている.

これに対して, Case R-1の流れにおいては, 半球下 流部の全域にわたり測定值と分布式はかなり適合度が悪 くなっていることが認められる.これは， $H / k$ が1.5〜 2 程度の流れにおいては, 半球下流部の $x / k$ が 4 〜 ではかなり大きな波状的な水面変動を生じ，また一方， 再付着域下流側には半球を越えて後流域に流れ込んだ流 れが路床面に沿って流れる，いわゆる波状跳水にやや類 似の現象を生じ，その結果，路床面側が加速され，水面 側は幾分減速された分布形をとるためと考えられる.こ れより, $H / k$ が $1.5 \sim 2$ 程度の，しかも波状的な水面変 動を生ずる流れに対しては，本報の領域分けによる取扱 いには無理があることを示している.

なお，粟津ら ${ }^{23)}$ の段落ち流れの報告にも，[水深/段落 高]の小さい場合には，その比のわずかな変化によって
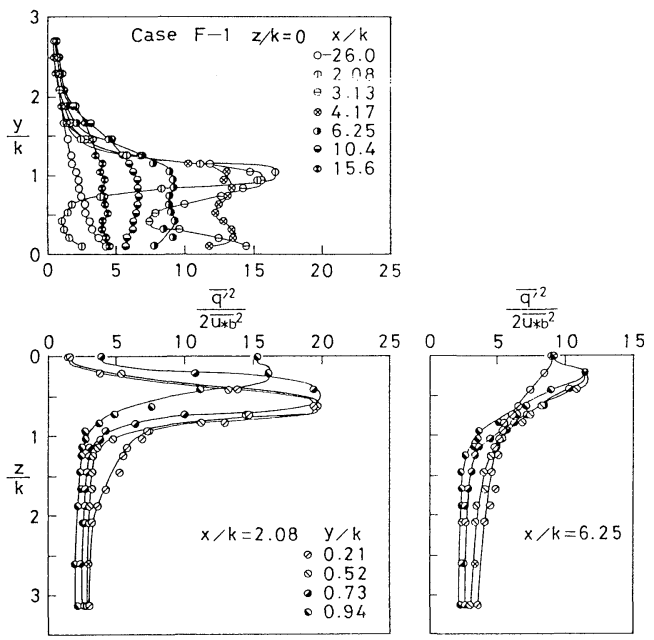

Fig. 8 Distribution of turbulent kinetic energy.
流況が複雑に変化することが指摘されており， $H / k$ が きわめて小さく，波状的な水面変動を生ずる流れに対し ては，さらに詳細な検討をする必要があろう。

\section{（2）乱れ特性}

a) 乱れエネルギーの分布

Fig. 8 は，半球下流部における乱れエネルギーの基本 的な分布特性を知るために, Case F-1 に対する半球の 流下中心軸を通る $[x-y]$ 面, および流れの構造の変化の 急激な半球頂面下方の $[x-z]$ 面における乱れエネル ギー $\bar{q}^{2} / 2 \bar{u}_{* b}^{2}$ の流下方向の変化を示したものである. この図上り, 半球下流部の剥離域と後流混合域との境界 のせん断層において生成された乱れエネルギ一は, 再付 着域の上流側の $x / k=2.08$ では，せん断層に沿って鋭 いピークを有し，いわゆる自由後流的な分布特性を示す ことが認められる. 一方，乱れエネルギ一は流下に伴っ て減衰していくとともに水深方向，横断方向に輸送，拡 散され平均化されていくが,特に再付着域直下流部では, せん断層に沿うピークのほかに路床面側にもかなり大量 の乱れエネルギーをもつ分布形を示すことが認められ る.この路床面側のピークに対応するものは自由後 流 $^{21), 24)}$ においては認められず，路床面の存在による特性 と考えられる. また, この路床面側の乱れエネルギーは, 後に示されるレイノルズ応力の再付着域下流側における 分布にはこのようなピークが明瞭には認められず，この 領域では乱れエネルギーに対するレイノルズ応力の比が

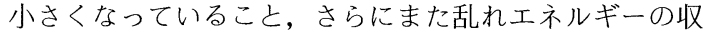
支の検討からもわかるように，その大部分は再付着域下 流部において生成されたものではなく，上流あるいはせ ん断層の領域から輸送, 拡散されたものであると考えら れる. 流下が進み $x / k$ が 15 程度になると, 後流混合域 の分布特性は多少残っているものの, 路床面側からしだ

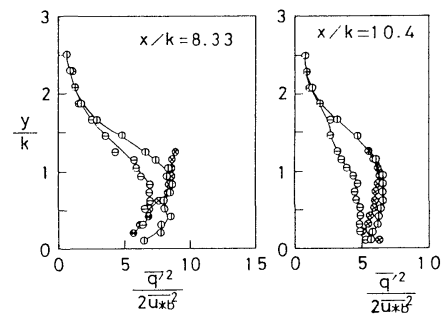

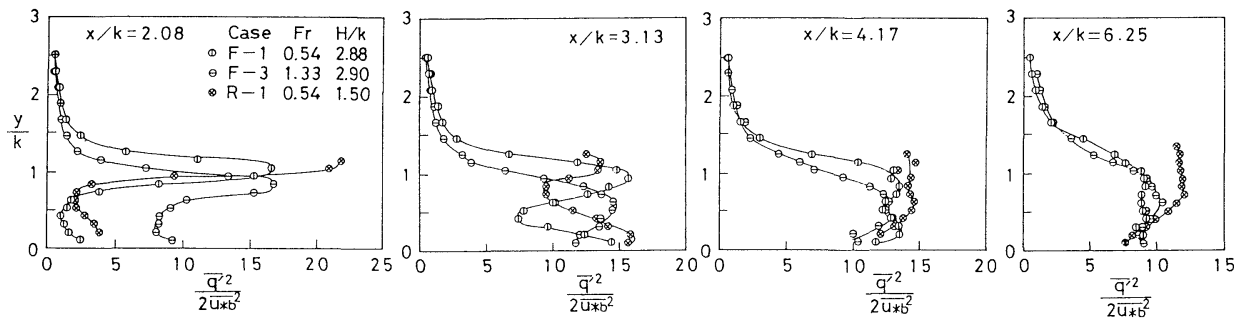

Fig. 9 Distributions of turbulent kinetic energy under different Froude number and water depth. 
いに接近流の分布に漸近していく傾向が認められ，壁面 境界層が再発達してきていることがうかがえる.

次に，乱れエネルギーの分布が，フルード数あるいは 相対水深の相違によってどのように変化するかを検討し たのがFig. 9 である. 常流の Case F-1 と射流の F-3 を比較すると, せん断層の位置の違いによって射流の方 がピークの位置がやや路床面側にずれるが, $x / k=2.08$ の路床面側を除いて, $x / k$ の 6 程度までは常流と射 流でほとんど同一のピークの大きさと分布形を示すこと がわかる. しかしながら, その後, F-3 の乱れエネルギー はF-1 に比べて流下に伴う減衰がより速やかとなり, F-3の $x / k=10.4$ においてはすでにF-1 の $x / k=15.6$ にかなり類似の分布形となることが認められる。なお， F-3の $x / k=2.08$ の路床面側の乱れエネルギーの増大 は, 剝離長さが F-1 に比べてやや短く,この領域の乱 れエネルギーの輸送, 拡散が幾分活発に行われているた めと考えられる.

一方，相対水深の小さい Case R-1においては， $x / k$ が 6 あるいは 8 程度までは, 水面近傍においてもかなり 大きな乱れエネルギーを有することが認められる．この 水面近くのかなり大きな乱れエネルギーの存在は, 前に 述べた, R-1 の流れにおいては $x / k$ の 4 程度までは 波状的な水面変動が生じ, その後この水面変動は徐々に 収まってくるという流況にほぼ対応していることから類 推して, かなりの部分が水面変動に伴う乱れの影響によ るものと推測される.この水面変動に伴う乱れの影響は, 穪津 ${ }^{25}$ によって乱流構造に及ぼす自由水面の影響として 検討されているように，いわゆる inactive 成分の寄与 として説明することができると考えられる.これはまた， 後の Fig. 12 に示されるレイノルズ応力（いわゆる active 成分）が, Case R-1 の $x / k=6.25$ あるいは 8.33 の水面近くにおいては水面に向かって減少しており,こ
の領域でレイノルズ応力による乱れエネルギーの生成は それほよ゙多くはないと考えられることからも推测され る.

Fig. 10 は，乱れエネルギ一の各方向成分の割合が流 下方向にビのように変化するかを, Case F-1に対して 示したものである.この図より，F-1においては，再 付着域の下流側で路床面側の $y$ 方向成分および, 特に $z$ 方向成分の割合が一時増大して, 乱れエネルギーの各 方向成分比がかなり均一化されることが， $x / k$ が $3 \sim 6$ の結果から認められる.これは, 半球上方および側方か らの流れ込みによる再付着域直下流部の流れの強い三次 元性によって乱れが等方化されるためと考えられるが, 流況の観察で認められる再付着域から上昇する，いわゆ る kolk-boil 渦の特性とも何らかの関連があるものと推 測される.また，射流のF-3 の流れにおいても，F-1 亡ほぼ類似の特性が認められている. 一方, R-1にお いては, F-1 に比べて路床面側の各成分の均一化はそ れほど顕著ではなく，むしろ水面側が均一化の傾向にあ ることが若干認められている.

Fig. 11 は, Case F-1 を例として, 半球下流部におい て乱れエネルギーの大きさが平均流エネルギーに対して ビれほどの比率になっているかをみるために，接近流に おけるその比率で無次元化した等エネルギー比のコン ターラインである. これより, 後流域においては, 平均

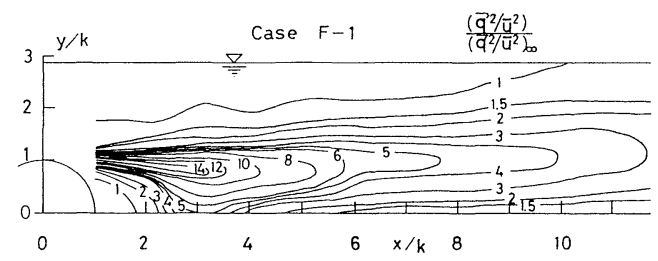

Fig. 11 Contours of the ratio of turbulent kinetic energy to mean flow energy.

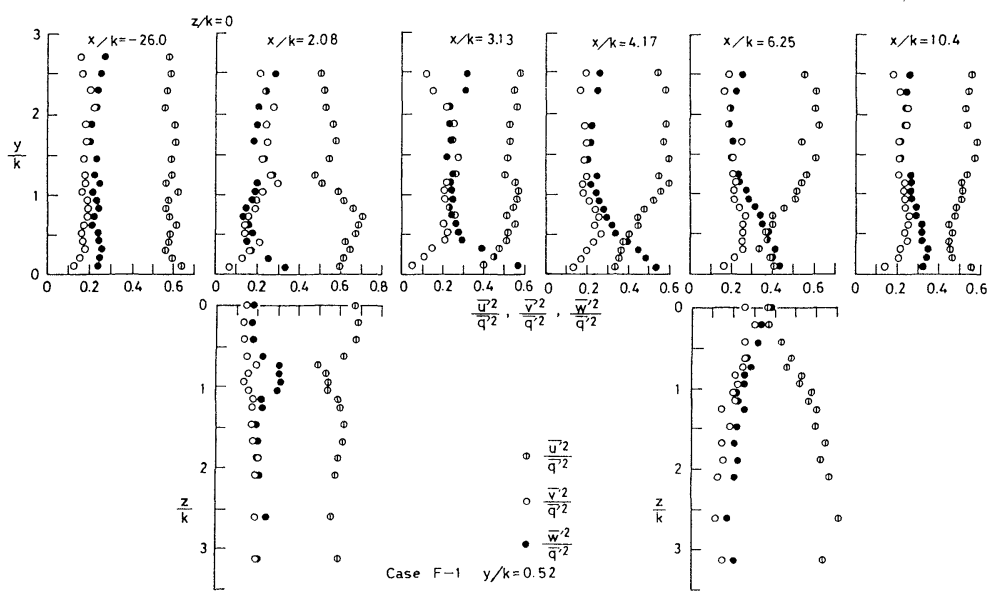

Fig.10 Distribution of turbulent kinetic energy components. 
流エネルギーの減少ならびに乱れエネルギーの増加に伴 い, 平均流エネルギーに対する乱れエネルギーの割合が 増大している. 特に半球直下流部においては，かなりの 高率に達していることが認められ，この領域において平 均流のエネルギーから乱れのエネルギーへの変換が活発 に行われていることがわかる。

b) レイノルズ応力

Fig. 12 は, 半球の流下中心軸上におけるレイノルズ 応力分布の流下方向の変化を示したものである．明瞭な ピークを示す領域 II における分布特性を検討するため に，図中には次式で表わされる軸対称の自由後流に対す るレイノルズ応力の分布式が曲線で示されている.なお, 式 (13) は, せん断応力の分布の相似性の仮定之式 ( 8 ), (11) および（9）から導かれる.

$$
\begin{aligned}
\frac{-\overline{u^{\prime} v^{\prime}}}{\bar{u}_{* b}^{2}}= & {\left[\frac{C_{D T}^{1 / 3}}{8.64 \sigma_{2}^{2}}\left(\frac{X_{0}}{k}\right)^{-4 / 3}\right.} \\
& \left.\cdot \xi \exp \left(-\frac{\xi^{2}}{1.44 \sigma_{2}^{2} C_{D T}^{2 / 3}}\right)\right] \frac{\bar{u}_{T}^{2}}{\bar{u}_{* b}^{2}}
\end{aligned}
$$

Case F-2 および F-3 のように $H / k>3$ の流れにおい ては, $x / k$ が $4 \sim 5$ 程度より下流の領域Iに対して, 全 体として式 (13) と測定值はほぼ一致していることが認 められる. また, 路床面近傍のごく一部を除いて，レイ ノルズ応力はそのほとんどが剝離域と後流混合域との境

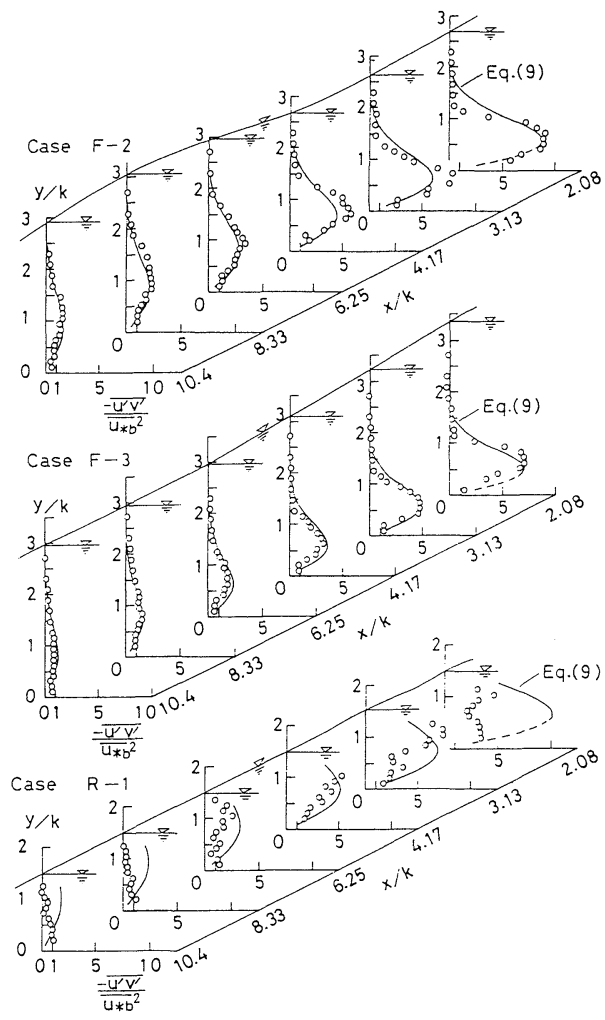

Fig. 12 Distributions of Reynolds stress.
界のせん断層において生成されることが理解される。し かしながら, 半球背後の高せん断層の領域に対しては, 実験方法ですでに述べたように，ホットフィルム流速計 による計測值は量的な面でやや信頼度に問題がありここ の領域に対して定量的により厳密な議論をするために は，計測手法の検討を含めて，さらに高精度の計測が要 求されよう. 次に， R-1においては，水深が小さく水 面が変動するために測定精度の問題が若干あり，また， 抗力係数がやや大きめに見積もられていることも考えら れるが，すでに平均流速の項で検討されたように流れは かなり複雑であり，このような流れに式（13）をそのま ま当てはめることには無理があることを示している．今 後 $H / k<1.5 \sim 2$ の流れに対しては，抗力係数の問題も 含めて，系統的な検討が必要であろう.

c) 乱れエネルギーとレイノルズ応力との相関

Fig. 13 は, 半球下流部における乱流構造の変化を検 討するために, Case F-1を例とした, 乱れエネルギー とレイノルズ応力との比- $\overline{u^{\prime} v^{\prime}} /\left(\bar{q}^{\prime 2} / 2\right)$ をとってその相 関性をみたものである.ばらつきが若干あり定量的には 幾分問題が残るが，定性的にみると，剝離域と後流混合 域の境界のせん断層の領域においてその比がピークを示 し， $x / k<10$ 程度までは乱れエネルギーに対するレイ ノルズ応力の割合が，接近流に比べてかなり増大してい ることが認められる.これは, 前項までに検討してきた ように，H/kがほぼ 3 よりも大きい流れでは，せん断 層の領域において乱れエネルギーとレイノルズ応力はと もにピークをもつが，その中でも，乱れエネルギーの生 成に寄与するような，いわゆる activeな乱れの占める 割合がこの領域で大きくなっていることを示している. 一方これに対して, 粗度により近い $x / k$ の $3 \sim 6$ 程度の 路床面側では, すでに Fig. 8 と 12 でも検討されたよう に, 乱れエネルギーが大きく，それに比べてレイノルズ 応力が小さいために active な乱れの占める割合がかな り減少していることが認められる.これより，この領域 では生成される乱れエネルギーに比べてせん断層領域か らの拡散, あるいは上流からの輸送による乱れエネル ギーがかなり大きな割合を占めるということが推論され る.

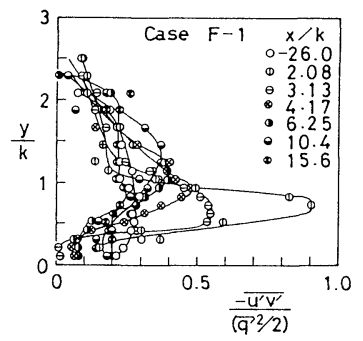

Fig. 13 Ratio of Reynolds stress to turbulent kinetic energy. 
d）乱れエネルギーの収支

半球下流部の流れにおける乱れエネルギ一方程式は, 粘性による拡散項および微小項を省略すると, 一般的に 次のように表わされる ${ }^{26)}$.

$$
\begin{aligned}
&- {\left[\bar{u} \frac{\partial}{\partial x}\left(\frac{\bar{q}^{\prime 2}}{2}\right)+\bar{v} \frac{\partial}{\partial y}\left(\frac{\bar{q}^{\prime 2}}{2}\right)+\bar{w} \frac{\partial}{\partial z}\left(\frac{\bar{q}^{\prime 2}}{2}\right)\right] } \\
&-\left[\overline{u^{\prime} v^{\prime}} \frac{\partial \bar{u}}{\partial y}+\overline{u^{\prime} w^{\prime}} \frac{\partial \bar{u}}{\partial z}\right]-\varepsilon-\left[\frac { \partial } { \partial y } \left\{\overline{v^{\prime} \cdot\left(\frac{q^{\prime 2}}{2}+\frac{p^{\prime}}{\rho}\right)}\right.\right. \\
&\left.+\frac{\partial}{\partial z}\left\{\overline{w^{\prime} \cdot\left(\frac{q^{\prime 2}}{2}+\frac{p^{\prime}}{\rho}\right)}\right\}\right]=0 \cdots \cdots \cdots \cdots \cdots \cdots \cdots \cdots(14)
\end{aligned}
$$

ここに, 左辺第 1 項は平均流による乱れエネルギーの輸 送率 (三Ad), 第 2 項は乱れエネルギーの生成率 $(\equiv P r)$, 第 3 項は乱れエネルギーの逸散率 $(\equiv \varepsilon)$, そして第 4 項は乱れ速度による乱れの運動および圧力エネルギーの 拡散率 (三D) である.

ここでは, 半球下流部における乱れエネルギーの収支 を半球の流下中心軸上の流れに対して検討することに し, 式 (14) の $z$ 方向の変化については考慮されてい ない.

Fig. 14 は, 半球下流部における乱れエネルギーの収 支が流下方向に上゙のように変化するかをみたものであ る. 図には, 各項がそれぞれ $\bar{u}_{* b}$ および $k$ で無次元化 されて示されている.ただし, 輸送率の值は, 2 項目の $\bar{v}$ は $\bar{u}$ に比べて十分に小さく，また測定精度の問題も あり評価が難しいため無視して，1 項目のみから算定さ れている. また, 逸散率は一次元エネルギースペクトル の慣性領域から算定されている. 一方, 拡散率は, 直接 算定が困難なために，式 (14) の残差として推定された.

この図より， $z$ 方向に対する収支を含めた検討がなさ れておらず，また，計測精度あるいは算定上の問題もあ り, 量的な面では問題があるが, 定性的には半球下流部
における乱れエネルギーの収支をある程度説明し得るよ うに思われる.すなわち，常流の Case F-1 をみると， 半球直下流の $x / k=2.08$ では, 剝離域と後流混合域境 界のせん断層で乱れエネルギーの生成率と逸散率はとも に最大值をとるが，ここでは大幅に生成率が逸散率を上 回るために乱れエネルギ一の過剰となる．この余剩の乱 れエネルギー（拡散項が負の部分）は $y$ 方向の乱れ速 度によって路床面ならびに水面方向に拡散され,さらに, これが輸送項に引き渡され（輸送項が負の部分）, 平均 流にのって下流方向に輸送されていることが説明され る. 一方, 再付着域直下流の $x / k=3.13$ においては, せん断層における乱れエネルギーの生成率は, ピークの 值はかなり減少するものの逸散率に比べると依然として 大きい.これに対して乱れエネルギ一は，せん断層の領 域と同時に路床面側でもかなりの量が逸散される.その 結果, せん断層の領域における乱れエネルギーの余剰分 は，大量に路床面方向に拡散されてその領域での不足分 を補い, さらに一部は, より下流への輸送分に引き渡さ れていることが理解される. また， $x / k=4.17$ におい ても, 路床面側の輸送項が一部, 負から正になるという ことを除いては， $x / k=3.13$ とほぼ同様な乱れエネル ギー収支の構造が認められる。これより, 再付着域直下 流部の $x / k$ の 3 に においては, 特にせん断層領域にお ける余剩エネルギ一の路床面方向への活発な拡散が顕著 であり，拡散項が重要な役割を占めていることが推論さ れる. 流下が進み $x / k$ が 6 程度になると， せん断層に おける生成率はかなり小さくなる。また，これに対して 逸散率も小さくなるが, 路床面側では逸散率の方が生成 率よりも大きくなるために乱れエネルギーの不足とな る. 一方, $x / k$ の 4 においてエネルギ一の運搬に大 きく寄与していた拡散項は，水面側では幾分認められる
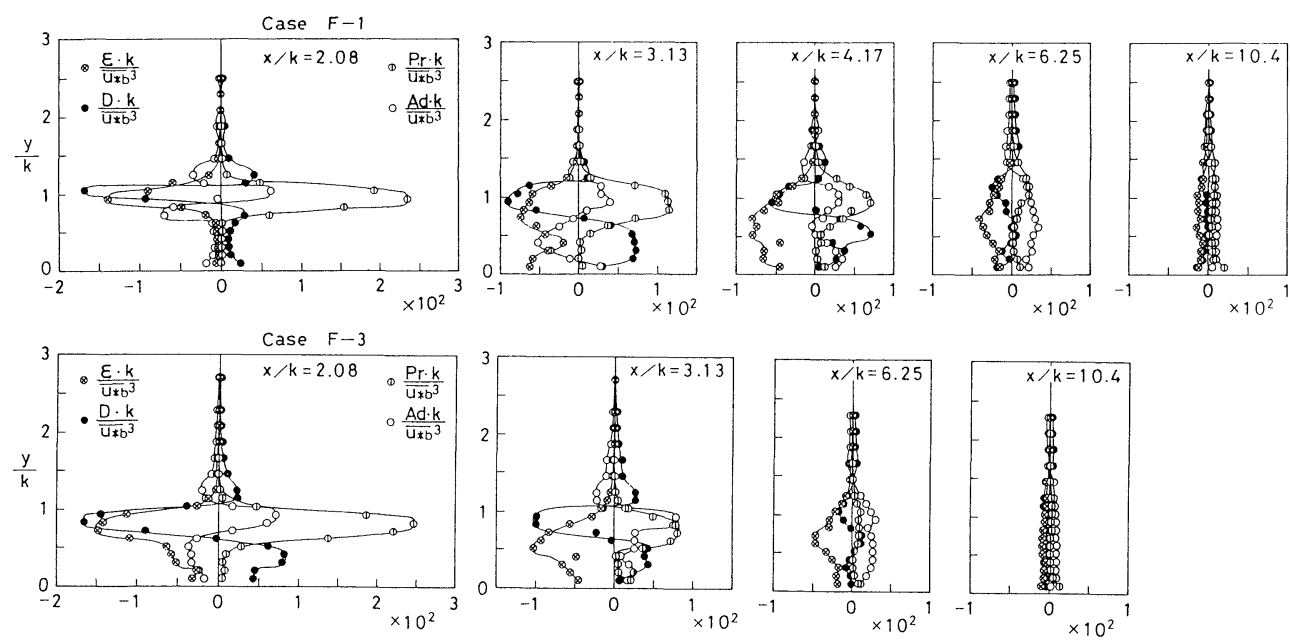

Fig. 14 Turbulent energy balance. 
ものの, 路床面側では $x / k$ の 3 に に比べて大幅に減少 しており,ここでの乱れエネルギーの不足分は, 主に上 流からの輸送によって補われていることが，輸送項が正 の分布を示すことから理解される.なお，特に $x / k=$ 3.13 あるいは 4.17 においては, 拡散率が若干アンバラ ンスになっているが，これは前にも述べたように，再付 着域直下流部の流れが非常に複雑になっており，また， $z$ 方向から半球の流下中心軸方向への乱れエネルギーの 拡散もあるためとも考えられるが，この領域に対するよ り詳細な議論をするためには, $z$ 方向の拡散も含めた三 次元的なエネルギー収支を検討することが必要であろ 引.

一方，射流の Case F-3 の乱れエネルギーの収支にお いては, 剝離長さが常流の F-1 に比べてやや短くなり, 再付着域が上流に寄るために， $x / k=3.13$ あるいは 4.17 における拡散項のエネルギー収支に寄与する割合 が常流よりも多少小さくなっていることがうかがえる. また， $x / k=10.4$ における生成率と逸散率は常流に比 ベて小さく，乱れエネルギーの減衰が全体的に速められ ていることもみられるが，定性的には，常流における乱 れエネルギー収支の構造にかなり類似の構造を示すこと が認められる。しかしながら，常流と射流に対する量的 に詳細な議論は, 計測の精度あるいは算定上の問題もあ り, 今後の課題であろう.

\section{4. むすび}

碟床河川における巨䃇の流れの抵抗等に及ぼす影響, あるいは根固めブロック等の河川構造物周辺の流れを検 討していくための基礎特性の把握を目的として，水路床 上に存在する半球下流部の $x / k<10$ 程度までの領域に おける流れの構造が, フルード数あるいは相対水深の相 違によってどのように変化するかを，平均流特性および 乱れ特性の面から実験結果をもとに検討したが，これを 要約すると次のようである.

（1）流れを，軸対称自由後流の特性が支配的な領域 と対数分布則が成り立つ領域の組合せ之仮定して，後流 の幅，平均流速分布，あるいはレイノルズ応力等の実験 結果と比較検討された. これより，後流の幅および半值 半幅の流下方向への広がりは, $\propto X_{0}^{1 / 3}$ となり, 二次元 後流に比べて, 幾分緩やかとなることが理解された.

（2）平均流速分布は， $H / k>3$ の流れの $x / k$ の 5 〜10の領域に対しては，上述の組合せに基づいた式と 測定值とのある程度の一致がみられた。しかしながら， それよりも上流側においては, 式の仮定の問題, 流れの 三次元性の影響により，分布式の適合性は路床面側で不 良となった。 また， $H / k$ が $1.5 \sim 2$ 程度の流れにおいて は, $x / k$ の 5 までの領域で波状的な水面変動を生ず
る波状跳水にやや類似の現象を示し，上述の領域分けに よる取扱いには無理があることが示された。

（3）乱れエネルギーの分布から，再付着域上流側で のせん断層に沿う鋭いピークをもつ自由後流的な特性と これが流下に伴って減衰していくとともに，周辺，下流 方向に拡散, 輸送されて平均化されていく過程が説明さ れた。特に，再付着域直下流部では，路床面の存在によ り，路床面側にも大量の乱れエネルギーを有する分布と なり，その大部分は拡散あるいは輸送されたものである ことが,乱れエネルギー収支の結果をもとに推測された. また，この部分では乱れが等方化され，乱れエネルギー の各方向成分の割合が均一化することが示され, 再付着 域から発生する三次元的な渦との関連が示唆された.

（4）射流の乱れエネルギ一の分布は， $x / k$ の $~ 6$ 程度までは常流とほとんど同じであるが，その後，流下 に伴う減衰がより速やかとなることが示された．また， $H / k$ が $1.5 \sim 2$ 程度の流れにおいては， $x / k$ の 6 8 程 度までは水面近傍においてもかなり大きな乱れ工ネル ギーを有することが認められ，これは，かなりの部分が 水面変動に伴う乱れの影響によるものと推測された.

（5）レイノルズ応力は， $H / k>3$ の流れでは，路床 面近傍の一部を除いて，そのほとんよ゙が剥離域と後流混 合域の境界のせん断層において生成され, $x / k$ の 4 より下流では, その分布の概形は軸対称自由後流に対す る分布式によってほぼ表現し得ることが示された.また， 乱れエネルギーとの相関より, activeな乱れの占める割 合がこの領域で増大していることが認められた。

（6）半球の流下中心軸上の乱れエネルギーの収支の 検討によって, エネルギ一が過剩域から不足域へ拡散, 輸送される過程が示され, 定性的には, 半球下流部の乱 流構造の変化を説明し得た. 特に, 再付着域直下流部で はせん断層領域における余剩エネルギーの路床面方向へ の拡散が顕著であり，さらに流下が進むと乱れエネル ギ一の不足分は主に上流からの輸送によって補われてい ることが示された。

以上, 半球下流部の流れの構造を検討してきたが, 半 球により近い領域に対する理論的取扱い，および $H / k$ がきわめて小さく, 波状的な水面変動を生ずる流れの構 造に関しては，さらに検討する必要があろう。また今後 は, この基本的な特性をもとに, 粗䃋の配列, 密度の相 違による流れの構造の変化等の, より工学的な問題にア プローチしたい.

最後に, 本研究を遂行するにあたり種々ご指導を賜っ た日本大学工学部 木村喜代治教授, 理工学部 粟津清蔵 教授, 工学部 長林久夫専任講師に, ここに深く感謝の 意を表します。また, 実験, 解析に尽力いただいた卒業 研究生諸氏に厚くお礼申し上げます。 
なお，本論文の公表にあたり，小川記念基金の補助を 受けた。記して謝意を表します。

\section{参 考 文 献}

1) 山岡 勲：河床上の矩形粗度が水路の抵抗に及ぼす効果 の研究, 北海道開発局土木試験所報告, 第 27 号, pp. 1 $\sim 55,1962$.

2) Gupta, V.P. et al. : Mean flow characteristics of redeveloping flows, Jour. Hydraulic Engineering, ASCE, Vol.113, No. 9, pp.1144 1158, 1987.

3）上野鉄男：波状路床上の流れにおける乱れ特性について (2)，京都大学防災研究所年報, 第 17 号 B, pp. 717 724, 1974.

4）佐々木成人・板倉忠興・岸 力：河床波上における乱 れの特性, 第 36 回土木学会年次講演会概要集, 1981.

5）今本博健 - 藤井良啓：開水路断面変化部における流れの 水理特性について (1), 京都大学防災研究所年報, 第 18 号 B, pp. $657 \sim 678,1975$.

6）今本博健 - 藤井義文 - 西尾 誠 - 田中一彦：開水路断面 変化部における流れの水理特性について ( 3 ), 京都大学 防災研究所年報, 第 21 号 B-2, pp. 331 353, 1978.

7）石川忠晴：断面急変に伴う剝離領域の下流部の流れと底 面せん断力について, 土木学会論文報告集, 第 257 号, pp. 21 29, 1977.

8) Mehta, P.R. : Flow characteristics in two-dimensional expansions, Proc. ASCE, Vol.105, No. HY5, pp.501 516, 1979.

9）襧津家久・中川博次・天野邦彦：開水路段落ちにおける 剝離流の乱流構造に関する研究, 第 30 回水理講演会論文 集, pp. 601 606, 1986.

10）爾津家久 - 中川博次 - 天野邦彦 - 藤本和久：開水路段落 ち流れの流速回復過程と再付着点からの組織渦の放出特 性, 第 31 回水理講演会論文集, pp. 413 418, 1987.

11) Chen, C.K. et al. : Turbulence in wakes of roughness elements, Proc. ASCE, Vol. 100, No. HY1, pp.53 67, 1974.

12）神田 徹・喜久里政宏 : 粗面上の薄層流の抵抗則に関す る実験的研究，第 23 回水理講演会論文集，pp. 339 346,
1979.

13) Okamoto, S. : Turbulent shear flow behind a sphere placed on a plane boundary, Turbulent Shear Flows 2, Springer-Verlag, New York, pp. 246 256, 1980.

14) Okamoto, S. : Turbulent shear flow behind hemispherecylinder placed on ground place, Turbulent Shear Flows 3, Springer-Verlag, New York, pp.171 185, 1982.

15）玉井信行・浅枝 隆・田中規夫：平板上の半球周りの流 れの構造について, 第 31 回水理講演会論文集, pp. 371 $\sim 376,1987$.

16）木村喜代治：辰方形水路における流れの一近似解析，土 木学会論文報告集, No. 251, pp. 45 57, 1976.

17）たとえば, Schlichting, H. : Boundary-layer theory, 7th ed., McGraw-Hill, 1979.

18) Hinze, J.O. : Turbulence, 2nd ed., McGraw-Hill, 1975.

19) Flammer, G.H. et al. : Free surface, velocity gradient flow past hemisphere, Proc. ASCE, Vol.96, No. HY7, pp. 1485 1502， 1970.

20）高橋迪夫・木村喜代治：半球粗度上の流れの抵抗と渦の 生成・離脱特性との相関に関する基礎的検討, 昭和 63 年 度土木学会東北支部発表会概要集, 1989.

21) Uberoi, M.S. et al. : Turbulent energy balance and spectra of the axisymmetric wake, Physics of Fluids, Vol. 13, No. 9, pp. 2205 2210, 1970.

22) Riley, J. J. et al. : Direct numerical simulations of the turbulent wake of an axisymmetric body, Turbulent Shear Flows 2, Springer-Verlag, New York, pp. 78 93, 1980.

23）栗津清蔵・大津岩夫 ·安田陽一：段落部における射流か ら常流への遷移, 土木学会第 43 回年次講演会概要集, 1988.

24) Carmody, T. : Establishment of the wake behind a disk, Jour. Basic Engineering, Trans. ASME, 86D, pp. 869 〜882, 1964.

25）爾津家久：開水路流の乱流構造に関する基礎的研究, 学 位論文, 1977 .

26）Rotta，J. C. (大路通雄訳)：乱流，岩波書店，1975.

(1989.4.11 • 受付) 